\title{
Presence of Basement Membrane Material around the Tubules of Tubulolobular Carcinoma
}

\author{
Gábor Cserni \\ Bács-Kiskun County Teaching Hospital, Kecskemét, Hungary
}

\section{Key Words}

Basement membrane - Breast cancer · Collagen IV . Tubulolobular carcinoma

\section{Summary}

Background: Core needle biopsies represent only a small portion of a breast lesion. Rare lesions with overlapping features may be underestimated in such small samples. Case Report: A 67-year-old female underwent core needle biopsy of a 27-mm breast tumour demonstrating infiltrative glands without significant desmoplasia. Periglandular collagen IV immunostaining and the small glands were reminiscent of microglandular adenosis, and despite the infiltrative look of the microglands, the lesion was interpreted as suspicious for malignancy. Finally, the tumour proved to be a tubulolobular carcinoma. Conclusions: The tubules of tubulolobular carcinoma may show a basement membrane-like staining pattern with collagen IV, and this must be considered in the differential diagnosis of mammary lesions with small glandular architecture.

\section{Introduction}

When Fisher et al. [1] first described tubulolobular carcinoma, they stated that it remained a philosophical question whether the growth pattern or the structure should be given more weight in the nomenclature and when placing this entity among tubular or lobular carcinomas. They opted for a variant of lobular carcinoma on the basis of the cellular composition

\author{
Schlüsselwörter \\ Basalmembran · Mammakarzinom · Kollagen IV . \\ Tubulolobuläres Karzinom
}

\section{Zusammenfassung}

Einleitung: Stanzbiopsien der Mamma enthalten stets nur kleine Anteile der bioptierten Läsion. Seltenere Läsionen mit überlappenden Anteilen können daher in solchen Proben unterbewertet werden. Fallbericht: Die Stanzbiopsie eines $27 \mathrm{~mm}$ großen Mammatumors einer 67-jährigen Patientin zeigte histologisch infiltrierende Drüsen ohne erkennbare Desmoplasie. Auf Grund eines immunhistologischen periglandulären Kollagen-IV-Nachweises wurde der Tumor trotz des infiltrativen Wachstumsmusters der kleinen Drüsen lediglich als «verdächtig für Malignität» eingestuft. Am Operationspräparat wurde schließlich ein tubulolobuläres Karzinom diagnostiziert. Schlussfolgerungen: Die Tubuli des tubulolobulären Karzinoms können basalmambranartige Kollagen-IVFärbungen aufweisen. Dies sollte bei der Differentialdiagnose von Mammaläsionen mit mikroglandulärer Architektur berücksichtigt werden.

\begin{tabular}{ll}
\hline KARGER & @ 2008 S. Karger GmbH, Freiburg \\
Fax +497614520714 & Accessible online at: \\
Information@Karger.de & www.karger.com/brc \\
www.karger.com &
\end{tabular}




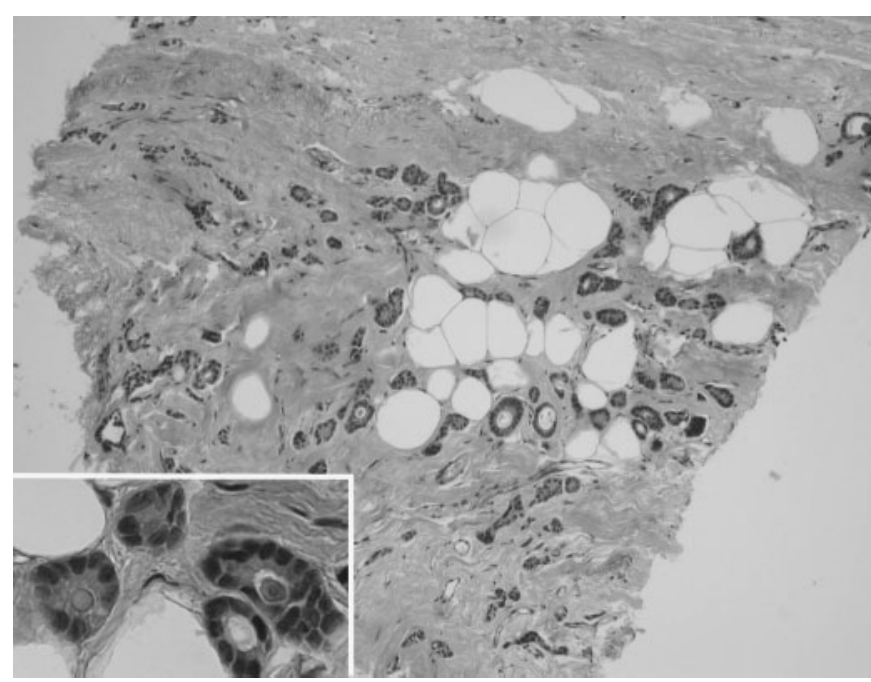

Fig. 1. Small infiltrative glands devoid of myoepithelium (HE $\times 100$; inset: HE $\times 400)$.

[4] E-cadherin-positive, and HMWCK stains most of them the same way as it stains lobular carcinomas [5].

Microglandular adenosis is a very rare pseudoneoplastic benign lesion of the breast which is characterised by small glands haphazardly arranged in a fibrofatty background [6,7]. It is devoid of myoepithelial cells and is therefore a mimic of well differentiated invasive carcinomas. It has a peculiar immunostaining pattern, and is reported to be distinctively EMA-negative and S-100-positive [8]. The presence of a basement membrane around the glands is also a recognised feature of the lesion [8].

\section{Case Report}

An ultrasound-guided core needle biopsy was obtained from a rightsided, non-palpable, but radiologically malignant lesion of a 67-year-old woman. Tissue was fixed in formalin and embedded in paraffin, and slides were stained with haematoxylin and eosin (HE). Small infiltrative glands were seen in a fibrofatty background (fig. 1). No desmoplastic stromal reaction was noted. The small glands clearly lacked myoepithelium, and some of them contained eosinophilic secretory material. Because of the small glands, microglandular adenosis was considered in the differential diagnosis. The infiltrative glands were epithelial membrane antigen-, oestrogen receptor- and progesterone receptor-positive, S-100-negative, and collagen IV but not laminin demonstrated a basement membraneequivalent staining pattern around them (fig. 2). The lack of a myoepithelial layer around the small glands strongly favoured a malignant preoperative diagnosis, especially in the light of the mammographic and ultrasonic images supporting such a diagnosis. Despite the fact that the immunophenotype did not support the diagnosis of microglandular adenosis, the core biopsy was interpreted as B4, suspicious of malignancy $[9,10]$, because of the disturbing presence of the periglandular collagen IV staining.

The patient underwent breast conserving surgery, and the final diagnosis of a sentinel lymph node-negative, $2.7-\mathrm{cm}$ tubulolobular carcinoma was issued from the resection specimen. The tumour predominantly displayed the microglandular infiltrative pattern seen in the core biopsy specimen,

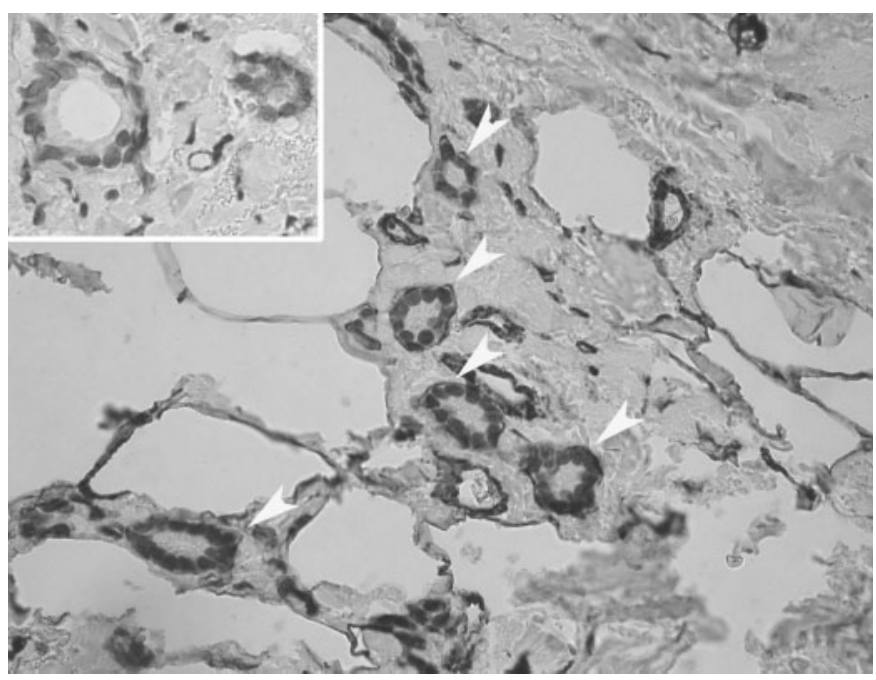

Fig. 2. Small infiltrating glands surrounded by a somewhat discontinuous rim of collagen IV-positive layer suggestive of a basement membrane (arrowheads). In contrast to collagen IV, laminin (inset) did not show any staining around the glands (collagen IV $\times 400$; inset: laminin $\times 400$ )

but also contained areas more reminiscent of classical lobular carcinoma. In keeping with the majority of publications, it demonstrated E-cadherin positivity $[2,5]$ and weak high-molecular-weight cytokeratin (HMWCK, 34Beta-E12) positivity [2].

\section{Discussion}

Both myoepithelial and basement membrane stains are generally recommended in the differential diagnosis of tubular or well differentiated ductal carcinomas versus microglandular adenosis or complex sclerosing lesions [8-10]. Very small glands can be seen, but are not the most typical in tubular carcinoma. Such glands are the features of microglandular adenosis, ductal carcinomas demonstrating a microglandular adenosis-like pattern [11], and classically, tubulolobular carcinoma which on the basis of the above considerations can be considered a misnamed special type of ductal cancers.

To note is the fact that the glands of tubulolobular carcinomas may display a basement membrane-equivalent staining pattern with collagen IV. Invasive breast carcinomas generally lack an epithelial basement membrane, although several authors have shown that a fragmented basement membrane can be visualised in a minority of cases with immunostains to laminin or collagen IV [12-15]. It was also proposed that the presence of basement membrane staining in carcinomas (always in a discontinuous pattern in contrast to the continuous staining seen in benign lesions) was correlated with better differentiation, and high grade cancers generally lacked staining or demonstrated more severe disruption of their basement membrane $[12,15]$. As current guidelines $[9,10]$ stress on the usefulness of basement membrane immunostains in differentiating benign (staining positively) from malignant (lacking staining) lesions, the presence of a slightly disrupted, nearly 


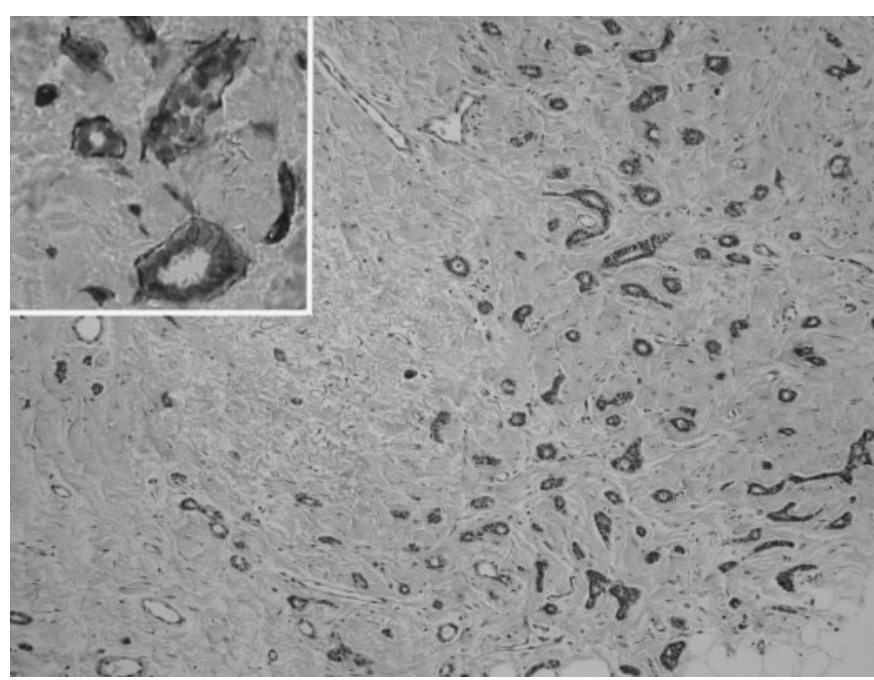

Fig. 3. Similar case of tubulolobular carcinoma from another patient; small infiltrating glands in this area and periglandular collagen IV staining (inset) $(\mathrm{HE} \times 100$; inset: collagen IV $\times 400)$

continuous staining pattern in some well differentiated breast carcinomas, including tubulolobular carcinoma with its small non-angulated glands, should be remembered when making the distinction between microglandular adenosis and these cancers. The mysterious perinodal tubules demonstrating focal peritubular collagen IV but not laminin staining recently reported by Nga and Putti [16] were also interpreted as extracapsular spread of a metastasis from an occult carcinoma with tubular features [17]. With this knowledge in mind, the core needle biopsy might and should have been interpreted as B5, diagnostic of malignancy $[9,10]$.

\section{Conclusions}

To support the notion in the title, a similar periglandular collagen IV (but not laminin) staining from another patient with Ecadherin-, EMA-, and HMWCK-positive and S-100-negative tubulolobular carcinoma is shown in figure 3. Benign apocrine glands devoid of myoepithelium have also been recently reported [18]. With this and the present case in mind, the dogmatic approaches suggesting that the presence of a basement membrane is diagnostic of a benign lesion or that the lack of a myoepithelial layer is a proof of malignancy should be considered with more caution, even if microglandular adenosis can be excluded on other grounds. A discontinuous basement membrane staining may not infrequently be present around the tubules of well differentiated breast carcinomas.

\section{References}

1 Fisher ER, Gregorio RM, Redmond C, Fisher B: Tubulolobular invasive breast cancer: a variant of lobular invasive cancer. Hum Pathol 1977;8: 679-683.

2 Marchio C, Sapino A, Arisio R, Bussolati G: A new vision of tubular and tubulo-lobular carcinomas of the breast, as revealed by 3-D modelling. Histopathology 2006;48:556-562.

3 Esposito NN, Chivukula M, Dabbs DJ: The ducta phenotypic expression of the E-cadherin/catenin complex in tubulolobular carcinoma of the breast: an immunohistochemical and clinicopathologic study. Mod Pathol 2007;20:130-138.

4 Kuroda H, Tamaru J, Takeuchi I, Ohnisi K, Sakamoto G, Adachi A, Kaneko K, Itoyama S: Expression of E-cadherin, alpha-catenin, and betacatenin in tubulolobular carcinoma of the breast. Virchows Arch 2006;448:500-505.

$\checkmark 5$ Wheeler DT, Tai LH, Brauthauer GL, Waldner DL, Tavassoli FA: Tubulolobular carcinoma of the breast: an analysis of 27 cases of a tumor with a hybrid morphology and immunoprofile. Am J Surg Pathol 2004;28:1587-1593.

6 Clement PB, Azzopardi JG: Microglandular adenosis of the breast - a lesion simulating tubular carcinoma. Histopathology 1983;7:169-180.

7 Rosen PP: Microglandular adenosis. A benign lesion simulating invasive mammary carcinoma. Am J Surg Pathol 1983;7:137-144.
8 Eusebi V, Foschini MP, Betts CM, Gherardi D, Millis RR, Bussolati G, Azzopardi JG: Microglandular adenosis, apocrine adenosis, and tubular carcinoma of the breast. An immunohistochemical comparison. Am J Surg Pathol 1993;17:99-109.

9 Ellis IO, Pinder SE, Bobrow L, Buley ID, Coyne J, Going JJ, Humphreys S, Jasani B, Lakhani S, Lowe J, Miller K, Rhodes A, Walker RA, Wells CA: Pathology reporting of breast disease. NHS Publication No 58. Sheffield, NHS Cancer Screening Programmes and the Royal College of Pathologists, 2005. www.cancerscreening.nhs.uk/breastscreen/publications/nhsbsp58-low-resolution.pdf (last viewed 16 February 2008).

10 Amendoeira I, Apostolikas N, Bellocq JP, Bianchi S, Boecker W, Borisch B, Bussolati G, Connolly CE, Cserni G, Decker T, Dervan P, Drijkoningen M, Ellis IO, Elston CW, Eusebi V, Faverly D, Heikkila P, Holland R, Kerner H, Kulka J, Jacquemier J, Lacerda M, Martinez-Penuela J, De Miguel C, Nordgren H, Peterse JL, Rank F, Regitnig P, Reiner A, Sapino A, Sigal-Zafrani B, Tanous AM, Thorstenson S, Zozaya E, Wells CA, EC Working Group on Breast Screening Pathology: Quality assurance guidelines for pathology; in Perry N, Broeders M, de Wolf C, Törnberg S, Holland R, von Karsa L (eds): European Guidelines for Quality Assurance in Breast Cancer Screening and Diagnosis, 4th ed. Luxemburg, European Comission, 2006, pp. 219311.
1 Shen SS, Sahin AA: Invasive ductal carcinoma of the breast with a microglandular adenosis pattern. Ann Diagn Pathol 2004;8:39-42.

12 Gusterson BA, Warburton MJ, Mitchell D, Ellison M, Neville AM, Rudland PS: Distribution of myoepithelial cells and basement membrane proteins in the normal breast and in benign and malignant breast diseases. Cancer Res 1982;42:4763-4770.

13 Guelstein VI, Tchypysheva TA, Ermilova VD, Ljubimov AV: Myoepithelial and basement membrane antigens in benign and malignant human breast tumors. Int J Cancer 1993;53:269-277.

14 Nerlich AG, Wiest I, Wagner E, Sauer U, Schleicher ED: Gene expression and protein deposition of major basement membrane components and TGFbeta in human breast cancer. Anticancer Res 1997; 17:4443-4449.

15 Zheng WQ, Looi LM, Cheah PL: A comparison of the patterns of laminin expression in fibroadenoma, fibrocystic diseases, pre-invasive and invasive ductal breast carcinoma. Pathology 2001;33:303306.

16 Nga ME, Putti TC: Glandular structures in an intraoperative axillary sentinel lymph node biopsy: a diagnostic dilemma. Histopathology 2005;48:475-477.

17 Cserni G: Axillary sentinel lymph node micrometastases with extracapsular extension: a distinct pattern of breast cancer metastasis? J Clin Pathol 2008;61:115-118.

18 Cserni G: Lack of myoepithelium in apocrine glands of the breast does not necessarily imply malignancy. Histopathology 2008;52:253-255. 